Applied Physiology, Nutrition, and Metabolism

Canadian Science Publishing Physiologie appliquée, nutrition et métabolisme

\title{
Calculating metabolic energy expenditure across a wide range of exercise intensities: the equation matters
}

\begin{tabular}{|r|l|}
\hline Journal: & Applied Physiology, Nutrition, and Metabolism \\
\hline Manuscript ID & apnm-2017-0781.R1 \\
\hline Manuscript Type: & Technical notes \\
\hline Date Submitted by the Author: & 10-Jan-2018 \\
\hline Complete List of Authors: & $\begin{array}{l}\text { Kipp, Shalaya; University of Colorado Boulder, Department of Integrative } \\
\text { Physiology } \\
\text { Byrnes, William; University of Colorado Boulder, Department of Integrative } \\
\text { Physiology } \\
\text { Kram, Rodger; University of Colorado Boulder, Department of Integrative } \\
\text { Physiology }\end{array}$ \\
\hline Keyword: & $\begin{array}{l}\text { Indirect calorimetry, expired gas analysis, metabolic rate, running } \\
\text { economy, respiratory exchange ratio }\end{array}$ \\
\hline $\begin{array}{r}\text { Is the invited manuscript for } \\
\text { consideration in a Special } \\
\text { Issue? : }\end{array}$ & N/A \\
\hline \multicolumn{2}{|c}{} \\
\hline
\end{tabular}

SCHOLARONE

Manuscripts 
Calculating metabolic energy expenditure across a wide range of exercise intensities: the equation matters

\author{
Shalaya Kipp, William C. Byrnes and Rodger Kram \\ Department of Integrative Physiology, University of Colorado, Boulder, CO \\ Corresponding Author: \\ Shalaya Kipp, M.S. \\ Department of Integrative Physiology \\ University of Colorado Boulder \\ 354 UCB \\ Boulder, CO 80309-0354 \\ Email: Shalaya.Kipp@,colorado.edu
}




\begin{abstract}
: 75 words or less for brief communication and tech notes
We compared ten published equations for calculating energy expenditure from oxygen consumption and carbon dioxide production using data for 10 high-caliber male distance runners over a wide range of running velocities. We found up to a $5.2 \%$ difference in calculated metabolic rate between two widely used equations. We urge our fellow researchers abandon outof-date equations with published acknowledgments of errors or inappropriate biochemical/physical assumptions.
\end{abstract}

Keywords: Indirect calorimetry, expired gas analysis, metabolic rate, running economy, respiratory exchange ratio 


\section{Introduction:}

Running economy (RE) is a primary physiological determinant of endurance running (Joyner, 1991). Traditionally, RE is defined as the mass specific rate of oxygen uptake required to run at a given submaximal velocity, where the oxygen required serves as a proxy for the metabolic energy expended. However, because different velocities/exercise intensities influence the ratio of carbohydrates $(\mathrm{CHO})$ and fats metabolized, and therefore the amount of energy liberated per liter of oxygen, more recent studies express RE as metabolic rate $(\mathrm{kcal} / \mathrm{min} / \mathrm{kg}$ or $\mathrm{W} / \mathrm{kg}$ ). By dividing oxygen uptake or metabolic rate by running velocity, one can alternatively calculate RE as the cost of transport (COT)- the amount oxygen or energy needed to transport a kilogram of body mass a given distance $\left(\mathrm{mlO}_{2} / \mathrm{kg} / \mathrm{km}, \mathrm{kcal} / \mathrm{kg} / \mathrm{km}\right.$ or $\left.\mathrm{J} / \mathrm{kg} / \mathrm{m}\right)$.

Fletcher et al. (2009) found that oxygen COT remained nearly constant across a range of running velocities, whereas when calculated in energy units, COT significantly increased with velocity. They concluded that expressing COT in units of energy was more sensitive to changes in intensity because it takes into account the different ratio of substrates metabolized at different submaximal velocities. Shaw et al. (2013) corroborated those findings, showing that COT in units of energy has greater validity than COT expressed in units of oxygen.

Indirect calorimetry is the most widely used technique for determining energy expenditure during exercise via the measurement of oxygen uptake $\left(\mathrm{VO}_{2}\right)$ and carbon dioxide production $\left(\mathrm{VCO}_{2}\right)$. Assuming that $\mathrm{VO}_{2}$ and $\mathrm{VCO}_{2}$ collected at the mouth accurately reflect metabolism at the tissues (i.e. respiratory exchange ratio $(\mathrm{RER})=$ respiratory quotient $(\mathrm{RQ})$ ), it is possible to calculate the mixtures of fuels being oxidized for energy. However, this is true only when the intensity of the exercise involves a metabolic steady state. 
Multiple published equations exist for calculating the energetic cost of exercise (Table 1). These equations calculate the rate of energy production $(-\Delta \mathrm{H})$ from measured $\mathrm{VO}_{2}$ and $\mathrm{VCO}_{2}$ in $\mathrm{L} / \mathrm{s}$, and excreted nitrogen $(\mathrm{N})$. Coefficients $\left(\mathrm{c}_{1}, \mathrm{c}_{2}, \mathrm{c}_{3}\right)$, for $\mathrm{VO}_{2}, \mathrm{VCO}_{2}$ and $\mathrm{N}$ are based upon the heat of combustion of various mixtures of $\mathrm{CHO}$, lipids and proteins oxidized (Equation 1).

$$
-\Delta \mathrm{H}(k J / s)=\mathrm{c}_{1}(k J / l) \cdot \mathrm{VO}_{2}+\mathrm{c}_{2}(k J / l) \cdot \mathrm{VCO}_{2}-\mathrm{c}_{3}(k J / g) \cdot \mathrm{N}(g)
$$

The coefficients $\left(c_{1}, c_{2}, c_{3}\right)$ in these equations differ in part due to small differences in the stoichiometry of the dietary species used. For example, humans consume a diet with a ratio of saccharides which differ slightly in their caloric values (supplementary table S1). Based on the chosen ratio of these different saccharides, a unique heat of combustion can be calculated for CHO. Additionally, the stoichiometry of fat metabolism also differs depending on the length of the fatty acids chosen.

Once proteins are broken down into amino acids and deaminated, the remaining ketoacids can be oxidized. Thus, the RER for expired gases reflects the metabolism of a mixture of $\mathrm{CHO}$, fats and proteins. However, because the contribution of protein as an energy source is so small, it has generally been considered negligible and ignored when estimating total energy expenditure during exercise (Brooks, 1997). Calculating protein oxidation requires measuring the excreted nitrogen in sweat and urine, or using radioactive isotopes. However, virtually all studies that use established equations for exercise energetics studies ignore the small nitrogen component.

Generally, it has been concluded that as long as the heats of combustion from dietary $\mathrm{CHO}$ and body lipids are correct, errors in estimating heat production based on the specific 
dietary species likely to lead to errors in estimating heat production less than 1\% (Blaxter 1962). However, a few studies have suggested that large errors are introduced depending upon whether CHO oxidation primarily involves glucose or glycogen (Ferrannini, 1988; Jeukendrup and Wallis, 2005). Further, Jeukendrup and Wallis (2005) suggested that because the intensity of exercise plays a role in the relative contributions of glucose and glycogen oxidized, assuming $100 \%$ glucose metabolized could overestimate energy expenditure by $8 \%$.

Our primary purpose was to compare multiple, published equations for calculating energy expenditure from expired gas analysis across a wide range of exercise intensities (i.e. running velocities) while assuming the protein contribution is nil. We hypothesized that there would be less than $1 \%$ difference in the calculated energy expenditure between the different equations.

\section{Methods:}

Participants

Ten high-caliber, male runners participated $(27.4 \pm 2.7$ years, $64.6 \pm 4.6 \mathrm{~kg}, 178.8 \pm 5.8 \mathrm{~cm})$. All had recently run a sub-31 minute $10 \mathrm{~km}$ race at sea level, or an equivalent performance in a different distance running event. Participants gave written informed consent that followed the guidelines of the University of Colorado Boulder IRB. We collected these data as part of a larger study (Kipp, 2017).

\section{Experimental set-up and protocol}

To habituate subjects to the treadmill and gas collection setup, they performed a series of running trials on a level motorized treadmill (Treadmetrix, Park City, UT). On Day 1, we verified that they could run submaximally during 5-minute trials at 14,16 and $18 \mathrm{~km} / \mathrm{hr}$. We 
measured $\mathrm{VO}_{2}$ and $\mathrm{VCO}_{2}$ with an open-circuit expired-gas analysis system (Parvomedics TrueOne 2400, Sandy, UT). We monitored [La] to assure a primary reliance on oxidative metabolism. To do so, we obtained 50uL of blood from the subject's fingers to determine lactate concentration ([La]) at rest and at the completion of each 5-minute stage and analyzed the blood with a YSI 2300 lactate analyzer (YSI, Yellow Springs, OH). Subjects who could run with a [La] below 4mmol/1 (Heck, 1985) and with an RER $<1.0$ were considered capable of running at all velocities submaximally. We acknowledge that with these criteria it is possible that some subjects still could be producing some non-metabolic $\mathrm{CO}_{2}$. However, the comparison of equations will not be influenced by small changes in non-metabolically produced $\mathrm{CO}_{2}$ in the small subset of subjects tested.

On Day 2, subjects arrived to the laboratory 2 hours postprandial to help control for potential effects of diet on metabolic rate. They ran six 5-minute trials (with 5-minute breaks) at velocities of $8,10,12,14,16$ and $18 \mathrm{~km} / \mathrm{hr}$ in randomized order, while we measured $\mathrm{VO}_{2}$ and $\mathrm{VCO}_{2}$. We calculated mean $\mathrm{VO}_{2}$ and $\mathrm{VCO}_{2}$ for the last 2-minutes of each trial and calculated metabolic rate using ten different equations (Table1) assuming zero protein metabolism. When needed, we converted units, so that all equations expressed metabolic power in $\mathrm{kJ} / \mathrm{s}$. We maintained the assumptions for energy release and substrate utilization of each paper.

\section{Statistics}

We calculated mean metabolic rates and standard deviations (SD) for each equation. To determine whether any differences existed between the equation used and velocity, we used RStudio (version 0.99.892, Boston, MA, USA) to perform a two-way repeated measures ANOVA followed by multiple pairwise comparisons using Tukey's honestly significant difference tests. Criterion of statistical significance was $P<0.05$. 


\section{Results:}

The Péronnet and Massicotte (1991) equation resulted in the highest calculated metabolic power, while the Weir (1949) equation resulted in the lowest calculated metabolic power. There was a significant $5.0-5.2 \%$ difference in calculated metabolic power between the Weir (1949) equation and Péronnet and Massicotte (1991) equation from 8 to $18 \mathrm{~km} / \mathrm{hr}(\mathrm{P}<0.001)$.

Additionally, there was a significant $3.8-3.7 \%$ difference in calculated metabolic power between the Ferrannini (1988) equation assuming 100\% glucose and the Péronnet and Massicotte (1991) equation $(\mathrm{P}=0.03)$. Similarly there was as $3.8-3.6 \%$ difference between calculated metabolic power between the Garby and Astrup equation and the Péronnet and Massicotte (1991) equation $(\mathrm{P}=0.04)$. The differences between equations were nearly constant across velocity, i.e. no interaction effect (Table 2).

There were numerical differences, but no statistical significant differences between the other equations. We found a $3.6 \% \pm 0.03$ mean numerical difference in calculated metabolic power between Brockway (1987) and Péronnet and Massicotte (1991) $(\mathrm{P}=0.055)$, and a 3.5\% \pm 0.03 mean difference in calculated metabolic power between the Ferrannini glycogen equation (1988) and Péronnet and Massicotte (1991) $(\mathrm{P}=0.069)$.

\section{Discussion:}

The equation used to calculate metabolic power can result in difference of up to $5.2 \%$. Thus, we reject our hypothesis that there would be less that a $1 \%$ difference in calculated energy expenditure regardless of the chosen equation. However, the relative differences in metabolic power calculated with different equations did not change across the velocity range we tested. 
The original Weir (1949) equation resulted in metabolic power values were $1.7 \%$ to $5.2 \%$ lower than all of the other equations we compared. Using Lusk's (1928) table of caloric values for CHO, Weir used Cathcart and Cuthbertson's (1931) updated analysis of human fats to propose an elegant and simple formula format for heat output that was adopted by many others that followed after him. However, Brockway (1987) pointed out Weir (1949) used what was most likely a typographic error in the published source data for fat from Cathcart and Cuthbertson (1931). Unfortunately, Weir's original equation is still being used by numerous studies. In the 2016 alone, Weir's original paper was cited 227 times. The Weir (1949) equation is presented in textbooks, programmed into indirect calorimetry software for resting energy expenditure (Parvo Medics TrueOne 2400), and used to create popular energy prediction equations (Pandolf et al., 1977). We feel that Weir still should be given credit for his contribution to the fields of physiology and metabolism but his original equation should be abandoned.

When considering which equation to use, Jeukendrup and Wallis (2005) suggested that to obtain more accurate results, exercise researchers should recognize the increased contribution of muscle and liver glycogen to overall $\mathrm{CHO}$ oxidation at greater exercise intensities. The molecular weight of glycogen $(162.143 \mathrm{~g}$, one glycosyl unit) is less than the molecular weight of glucose $(180.158 \mathrm{~g})$, and thus oxidized glycogen releases more energy on a per gram basis (glucose-15.64 kJ/g vs. glycogen-17.50 kJ/g). However, our data showed that when we utilized the Jeukendrup and Wallis equations over our wide range of intensities, there was no significant difference from more traditional equations that assume $100 \%$ glucose. It has been reported that at moderate to high exercise intensities $\left(>75 \% \mathrm{VO}_{2} \mathrm{max}\right)$ muscle glycogen can account for $75-85 \%$ of the CHO oxidation (Romijn et al., 1993, van Loon et al., 2001). However, during lower 
intensity exercise, the ratio of glucose vs. glycogen utilized are less clear. Empirical studies have reported at intensities below $50 \% \mathrm{VO}_{2}$ max, the contribution of glycogen to overall $\mathrm{CHO}$ oxidation to be can be as high as $77 \%$ (van Loon et al., 2001) or as low as $0 \%$ (Romijn et al., 1993). Theoretically, at higher intensities, Jeukendrup and Wallis' (2005) equations could be more accurate. While there is some controversy over the contribution blood glucose plays during exercise, our results do not support an equation effect for varying the carbohydrate energy sources.

The stoichiometry of fat metabolism varies depending on the length of the fatty acid chain. Lusk (1923) used published data on pork lard to determine fat oxidation. Equations to follow used palmitic acid or similar fatty acids because they are abundant in the human diet (Ferrannini, 1988; Frayn, 1983), where $1 \mathrm{~g}$ palmitic acid $\left(\mathrm{C}_{16} \mathrm{H}_{32} \mathrm{O}_{2}\right)$ yields $39.75 \mathrm{~kJ}$. Péronnet and Massicotte (1991) took a more meticulous approach, reporting the respective average of 13 fatty acids that represent more than $99 \%$ of the fatty acids found in human triacylglycerols, where $1 \mathrm{~g}$ of the averaged fatty acids $\left(\mathrm{C}_{17.2702} \mathrm{H}_{32.7142} \mathrm{O}_{2}\right)$ yields $40.79 \mathrm{~kJ}$.

In addition to slight differences in the dietary species used to create the equation, Péronnet and Massicotte (1991), note that oxygen and carbon dioxide are not ideal gasses as previous equations have treated them. One mole of oxygen actually occupies 22.3858 liters STPD and one mole of carbon dioxide actually occupies 22.2966 liters STPD (Weast, 1972). For example, consider the oxidation of glucose where $2817 \mathrm{~kJ}$ of heat are released.

$$
\mathrm{C}_{6} \mathrm{H}_{12} \mathrm{O}_{6}+6 \mathrm{O}_{2} \rightarrow 6 \mathrm{CO}_{2}+6 \mathrm{H}_{2} \mathrm{O}+2817 \mathrm{~kJ}
$$

Since 6 moles of oxygen are required for oxidation, one mole of glucose requires $6 \times 22.41 \mathrm{~L}$. The ratio of heat produced to oxygen consumed then becomes $2817 /(6 \times 22.41)$ or $20.95 \mathrm{~kJ} / \mathrm{L}$. However, if $22.3858 \mathrm{~L} / \mathrm{mol}$ is used, $20.97 \mathrm{~kJ} / \mathrm{L}$ is actually released. Using the common 22.41 
$\mathrm{L} / \mathrm{mol}$ for an ideal gas leads to slight underestimations of the energy equivalent per liter of gas. Accounting for oxygen and carbon dioxide not being ideal gases and the higher energy fat species utilized partly explains why the Péronnet and Massicotte's (1991) equation results in the greatest metabolic power values.

For most within study designs, the equation used might seem irrelevant, but when comparing across studies, it is important to consider which equations were used to calculate metabolic rate. We encourage researchers to report both $\mathrm{VO}_{2}$ and $\mathrm{VCO}_{2}$, or $\mathrm{VO}_{2}$ and RER to allow readers to calculate energy expenditure using a common equation. Additionally, we urge investigators to abandon out-of-date equations with published acknowledgments of errors or inappropriate biochemical/physical assumptions.

\section{Conflict of interest statement}

The authors declare no conflict of interest.

\section{References:}

Blaxter, K. L. 1962. The fasting metabolism of adult wether sheep. Br. J. Nutr. 16(1): 615-626.

Brooks, G. A. 1997. Importance of the 'crossover' concept in exercise metabolism. Clin. Exp. Pharmacol. Physiol. 24(11): 889-895. doi:10.1111/j.1440-1681.1997.tb02712. PMID:9363377.

Brockway, J. M. 1987. Derivation of formulae used to calculate energy expenditure in man. Hum. Nutr. Clin. Nutr. 41(6): 463-471. PMID:3429265.

Cathcart, E. P., and Cuthbertson, D. P. 1931. The composition and distribution of the fatty substances of the human subject. J. Physiol. 72(3): 349-360. doi: 10.1113/jphysiol.1931.sp002779. PMID:16994214 
Ferrannini, E. 1988. The theoretical bases of indirect calorimetry: a review. Metab. 37(3): 287-301. doi.org/10.1016/0026-0495(88)90110-2. PMID:3278194.

Fletcher, J. R., Esau, S. P., and MacIntosh, B. R. 2009. Economy of running: beyond the measurement of oxygen uptake. J. Appl. Physiol. 107(6): 1918-1922. doi.org/10.1152/japplphysiol.00307.2009. PMID:19833811.

Frayn, K. N. 1983. Calculation of substrate oxidation rates in vivo from gaseous exchange. J. Appl. Physiol. 55(2): 628-634. doi:10.1152/jappl.1983.55.2.628. PMID:6618956.

Garby, L., and Astrup, A. 1987. The relationship between the respiratory quotient and the energy equivalent of oxygen during simultaneous glucose and lipid oxidation and lipogenesis. Acta Physiologica, 129(3): 443-444. doi:10.1111/j.1365-201X.1987.tb10613. PMID:3577829.

Heck, H., Mader, A., Hess, G., Mücke, S., Müller, R., and Hollmann, W. 1985. Justification of the 4mmol/1 lactate threshold. Int. J. Sports Med. 6(3): 117-130. doi:10.1055/s-2008-1025824.

PMID:4030186.

Jeukendrup, A. E., and Wallis, G. A. 2005. Measurement of substrate oxidation during exercise by means of gas exchange measurements. Int. J. Sports Med. 26(S1): S28-S37. doi:10.1055/s-2004830512. PMID:15702454.

Joyner, M. J. 1991. Modeling: optimal marathon performance on the basis of physiological factors. J. Appl. Physiol. 70(2): 683-687. doi:10.1152/jappl.1991.70.2.683. PMID:2022559.

Kipp, S. 2017. Why does metabolic rate increase curvilinearly with running velocity?. M.S. thesis, Boulder: University of Colorado.

Lusk, G. 1924. Animal calorimetry twenty-fourth paper. Analysis of the oxidation of mixtures of carbohydrate and fat. J. Biol. Chem. 59(1): 41-42.

McLean, J. A., and Tobin, G. 1987. Animal and human calorimetry. Cambridge University Press, United Kingdom. pp. 31.

Pandolf, K. B., Givoni, B., and Goldman, R. F. 1977. Predicting energy expenditure with loads while standing or walking very slowly. J. Appl. Physiol. 43(4): 577-581. doi:10.1152/jappl.1977.43.4.577. PMID:908672.

Péronnet, F., and Massicotte, D. 1991. Table of nonprotein respiratory quotient: an update. Can. J. Sport Sci. 16(1): 23-29. PMID:1645211.

Romijn, J. A., Coyle, E. F., Sidossis, L. S., Gastaldelli, A., Horowitz, J. F., Endert, E., and Wolfe, R. R. 1993. Regulation of endogenous fat and carbohydrate metabolism in relation to exercise intensity and 
duration. Am. J. Physiol. Endocrinol. Metab. 265(3): E380-E391. doi:10.1152/ajpendo.1993.265.3.E380. PMID:8214047.

Shaw, A. J., Ingham, S. A., Fudge, B. W., and Folland, J. P. 2013. The reliability of running economy expressed as oxygen cost and energy cost in trained distance runners. Appl. Physiol. Nutr. Metab. 38(12): 1268-1272. doi:10.1139/apnm-2013-0055. PMID:24195628.

van Loon, L. J., Greenhaff, P. L., Constantin-Teodosiu, D., Saris, W. H., and Wagenmakers, A. J. 2001. The effects of increasing exercise intensity on muscle fuel utilisation in humans. J. Physiol. 536(Pt 1): 295. doi:10.1111/j.1469-7793.2001.00295.x. PMID:11579177.

Weir, J. D. V. 1949. New methods for calculating metabolic rate with special reference to protein metabolism. J. Physiol. 109(1-2): 1-9. PMID:2136000

Weast, R. C. (Ed.). 1972. Handbook of Chemistry and Physics $53^{\text {rd }}$ Edition. CRC. Cleveland, Ohio. 
Table 1. Published equations for calculating the energetic expenditure, where $\mathrm{VO}_{2}$ and $\mathrm{VCO}_{2}$ is in $\mathrm{L} / \mathrm{s}$, and $\mathrm{N}$ is in $\mathrm{g}$.

\begin{tabular}{|c|c|}
\hline & Equation \\
\hline Lusk, 1923 $^{\mathrm{a}}$ & $16.00 \mathrm{VO}_{2}+5.15 \mathrm{VCO}_{2}-7.80 \mathrm{~N}$ \\
\hline Weir, 1949 & $16.50 \mathrm{VO}_{2}+4.62 \mathrm{VCO}_{2}-9.06 \mathrm{~N}$ \\
\hline Weir ${ }^{\mathrm{b}}$ (corrected) & $16.62 \mathrm{VO}_{2}+4.51 \mathrm{VCO}_{2}-9.22 \mathrm{~N}$ \\
\hline Garby and Astrup, 1987 & $16.04 \mathrm{VO}_{2}+4.94 \mathrm{VCO}_{2}$ \\
\hline Ferrannini, 1988 (glucose) & $16.15 \mathrm{VO}_{2}+4.82 \mathrm{VCO}_{2}-4.79 \mathrm{~N}$ \\
\hline Ferrannini, 1988 (glycogen) & $16.38 \mathrm{VO}_{2}+4.64 \mathrm{VCO}_{2}-4.51 \mathrm{~N}$ \\
\hline Brockway, 1987 & $16.58 \mathrm{VO}_{2}+4.51 \mathrm{VCO}_{2}-5.90 \mathrm{~N}$ \\
\hline $\begin{array}{l}\text { Péronnet and Massicotte, } \\
1991\end{array}$ & $16.89 \mathrm{VO}_{2}+4.84 \mathrm{VCO}_{2}$ \\
\hline $\begin{array}{l}\text { Jeukendrup and Wallis, } \\
2005 \text { (Intensities between } \\
40-50 \% \mathrm{VO}_{2} \mathrm{max} \text { ) }\end{array}$ & $18.56 \mathrm{VO}_{2}+2.40 \mathrm{VCO}_{2}-4.14 \mathrm{~N}$ \\
\hline $\begin{array}{l}\text { Jeukendrup and Wallis, } \\
\text { 2005 (Intensities between } \\
\text { 50-75\% VO丶 }\end{array}$ & $18.71 \mathrm{VO}_{2}+2.30 \mathrm{VCO}_{2}-4.14 \mathrm{~N}$ \\
\hline
\end{tabular}

${ }^{a}$ as calculated by Abramson et al., 1942.

${ }^{\mathrm{b}}$ Weir's equation as corrected in Brockway, 1987. 
Table 2. Metabolic rate calculated using each equation. * indicates $P<0.05$ when compared to Peronnet \& Massicotte for the same corresponding velocity. Values presented are means $\pm \mathrm{SD}$.

\begin{tabular}{|c|c|c|c|c|c|c|c|c|c|}
\hline $\begin{array}{l}\text { Velocity } \\
(\mathrm{km} / \mathrm{hr})\end{array}$ & $\begin{array}{l}\text { Weir, } 1949 \\
\text { (W/kg) }\end{array}$ & $\begin{array}{c}\text { Ferrannin, } \\
1988 \\
\text { glucose } \\
\text { (W/kg) }\end{array}$ & $\begin{array}{c}\text { Garby and } \\
\text { Astrup, } \\
1987 \\
(W / k g)\end{array}$ & $\begin{array}{c}\text { Brockway, } \\
1987 \\
(\mathrm{~W} / \mathrm{kg})\end{array}$ & $\begin{array}{c}\text { Ferrannini, } \\
1988 \\
\text { glycogen } \\
\text { (W/kg) }\end{array}$ & $\begin{array}{l}\text { Lusk, } \\
1923 \\
\text { (W/kg) }\end{array}$ & $\begin{array}{c}\text { Weir } \\
\text { corrected } \\
\text { (W/kg) }\end{array}$ & $\begin{array}{l}\text { Jeukendrup } \\
\text { and Wallis, } \\
2005 \text { (W/kg) }\end{array}$ & $\begin{array}{l}\text { Péronnet and } \\
\text { Massicotte, } \\
1991(\mathrm{~W} / \mathrm{kg})\end{array}$ \\
\hline 8 & $\begin{array}{l}8.79^{*} \\
\pm 0.49\end{array}$ & $\begin{array}{l}8.91^{*} \\
\pm 0.52\end{array}$ & $\begin{array}{l}8.93^{*} \\
\pm 0.52\end{array}$ & $\begin{array}{c}8.94 \\
\pm 0.49\end{array}$ & $\begin{array}{c}8.95 \\
\pm 0.52\end{array}$ & $\begin{array}{c}8.97 \\
\pm 0.52\end{array}$ & $\begin{array}{c}9.01 \\
\pm 0.53\end{array}$ & $\begin{array}{c}9.10 \\
\pm 0.56\end{array}$ & $\begin{array}{c}9.26 \\
\pm 0.54\end{array}$ \\
\hline 10 & $\begin{array}{l}10.40 * \\
\pm 0.56\end{array}$ & $\begin{array}{l}10.55^{*} \\
\pm 0.61\end{array}$ & $\begin{array}{l}10.55^{*} \\
\pm 0.61\end{array}$ & $\begin{array}{l}10.58 \\
\pm 0.57\end{array}$ & $\begin{array}{l}10.58 \\
\pm 0.61\end{array}$ & $\begin{array}{l}10.62 \\
\pm 0.61\end{array}$ & $\begin{array}{l}10.66 \\
\pm 0.62\end{array}$ & $\begin{array}{l}10.75 \\
\pm 0.62\end{array}$ & $\begin{array}{l}10.96 \\
\pm 0.63\end{array}$ \\
\hline 12 & $\begin{array}{l}12.17^{*} \\
\pm 0.76\end{array}$ & $\begin{array}{l}12.35^{*} \\
\pm 0.84\end{array}$ & $\begin{array}{l}12.35^{*} \\
\pm 0.85\end{array}$ & $\begin{array}{l}12.38 \\
\pm 0.77\end{array}$ & $\begin{array}{l}12.39 \\
\pm 0.84\end{array}$ & $\begin{array}{l}12.43 \\
\pm 0.85\end{array}$ & $\begin{array}{l}12.48 \\
\pm 0.85\end{array}$ & $\begin{array}{l}12.57 \\
\pm 0.86\end{array}$ & $\begin{array}{l}12.83 \\
\pm 0.87\end{array}$ \\
\hline 14 & $\begin{array}{l}14.49^{*} \\
\pm 0.64\end{array}$ & $\begin{array}{l}14.70^{*} \\
\pm 0.75\end{array}$ & $\begin{array}{l}14.71^{*} \\
\pm 0.75\end{array}$ & $\begin{array}{l}14.74 \\
\pm 0.65\end{array}$ & $\begin{array}{r}14.75 \\
\pm 0.75\end{array}$ & $\begin{array}{l}14.81 \\
\pm 0.75\end{array}$ & $\begin{array}{l}14.86 \\
\pm 0.76\end{array}$ & $\begin{array}{l}15.00 \\
\pm 0.78\end{array}$ & $\begin{array}{l}15.27 \\
\pm 0.78\end{array}$ \\
\hline 16 & $\begin{array}{l}17.31^{*} \\
\pm 0.92\end{array}$ & $\begin{array}{l}17.58^{*} \\
\pm 1.01\end{array}$ & $\begin{array}{l}17.59^{*} \\
\pm 1.01\end{array}$ & $\begin{array}{l}17.61 \\
\pm 0.94\end{array}$ & $\begin{array}{l}17.63 \\
\pm 1.01\end{array}$ & $\begin{array}{l}17.71 \\
\pm 1.02\end{array}$ & $\begin{array}{l}17.76 \\
\pm 1.01\end{array}$ & $\begin{array}{l}17.86 \\
\pm 0.99\end{array}$ & $\begin{array}{l}18.25 \\
\pm 1.04\end{array}$ \\
\hline 18 & $\begin{array}{c}20.38^{*} \\
\pm 0.91\end{array}$ & $\begin{array}{c}20.72^{*} \\
\pm 0.96\end{array}$ & $\begin{array}{c}20.73^{*} \\
\pm 0.97\end{array}$ & $\begin{array}{l}20.75 \\
\pm 0.92\end{array}$ & $\begin{array}{l}20.78 \\
\pm 0.97\end{array}$ & $\begin{array}{l}20.89 \\
\pm 0.97\end{array}$ & $\begin{array}{l}20.92 \\
\pm 0.97\end{array}$ & $\begin{array}{l}20.92 \\
\pm 0.99\end{array}$ & $\begin{array}{l}21.51 \\
\pm 1.00\end{array}$ \\
\hline
\end{tabular}

